\title{
Detection of Volcanic Smoke and Ash-Fall Area at Volcano Aso, from Landsat MSS Data
}

\author{
by \\ Yasuhiro Tanaka \\ Meteorological Research Institute, Tsukuba, Japan \\ Kiyoshi Tsuchiya and Yuichi Yamaura \\ National Space Development Agency of Japan \\ (Received Aug. 5, 1981 ; Revised Oct. 2, 1981)
}

\begin{abstract}
Volcano Aso had frequent eruptions from 1979 through 1980, and a large amount of volcanic smoke and ash was emitted from its crater. The area spread over by the volcanic smoke and the area covered by the volcanic ash of this period were investigated by the optical analysis method of the Landsat MSS image.

Volcanic smoke and ash-fall area were clearly detected from the Landsat MSS image. Their detectable area was seen to change with the transition of volcanic activity, and the maximum extension of volcanic smoke was about $70 \mathrm{~km}$ from the crater, and that of volcanic ash-fall area was about $10 \mathrm{~km}$ around the crater.

By observation from the Landsat, it is possible to get information on the wide horizontal distribution of volcanic smoke or ash-fall, and the data from the Landsat are very useful for volcano observation.
\end{abstract}

\section{Introduction}

The purpose of the present investigation is to show how to utilize the images taken from the satellite for volcano observation.

The volcanic smoke and ash due to a large eruption are spread out so extensively that ground observation of the phenomena and the area affected is difficult. Therefore, the need of wide areal observation from the air is keenly felt.

As to usefulness of satellites for observation of volcanic activities, the following data which summarize Friedman et al. (1976) are worthy of special attention.

The 1966 eruption of Surtsey in Iceland was photographed by the NIMBUS-2 satellite, the 1970 eruption of Beerenberg volcano in Jan Mayen Island by the ESSA-8 satellite, the 1973 eruption of Heimaey volcano in Iceland by the ERTS-1 (renamed Landsat-1) satellite, the 1974 eruption of Mount Etna in Sicily Island and Fuego volcano in Guatemala by the SKYLAB-4 satellite, the 1974 eruption of Tiatia volcano in Kunashir of Kuril Island by the Landsat-1 satellite, and the 1976 eruption of Fernandina volcano in the Galápagos Islands by the SKYLAB-4 satellite. They also studied the photographs of the volcanic smoke of Sakurajima volcano in Japan, taken from the SKYLAB-4 satellite from 1973 through 1974.

From the above, we see that the history of observation of volcanic phenomena from the satellite is not yet a long one. Detectable volcanic smoke is limited to the time of a large-scale eruption at many different volcanoes, and no study has been done about 
the transition of volcanic activities of a given volcano.

Therefore, the present authors have taken up the series of volcanic activities of a given volcano, using the satellite image.

Volcano Aso located at central Kyushu, Japan $\left(33^{\circ} 53^{\prime} \mathrm{N}, 131^{\circ} 05^{\prime} \mathrm{E}, 1592 \mathrm{~m}\right.$ above sea level), had frequent eruptions from the middle of 1979 to the beginning of 1980 , and a large amount of volcanic smoke and ash was emitted from the crater and spread out over an extensive area. The observation of volcanic smoke of this volcano is routinely carrid out by the Asosan Weather Station, located 1.2 $\mathrm{km}$ west-southwest of the active crater. Although the detailed features of the volcanic smoke around the summit can be obtained from the ground by eye observation, the spatial extension of the smoke and ash-fall is beyond its scope.

On the other hand, the earth observation satellite "Landsat" can observe $180 \mathrm{~km}$ width with $80 \mathrm{~m}$ spatial resolution along the track. Therefore, taking advantage of the high resolution of Landsat data, the authors intend to clarify the extent of volcanic smoke and ash-fall associated with the eruption activity of Volcano Aso in 1979 and 1980. The result of the analysis will be compared with that of the routine observation data of the Asosan Weather Station.

\section{Landsat and its image}

Landsat is an earth observation satellite launched and operated by NASA (National Aeronautics and Space Administration). It has two sensors, MSS (Multi Spectral Scanner) and RBV (Return Beam Vidicon) camera and observes the same place every 18 days. MSS has sensitibity in 4 spectral ranges $(0.5$ to $0.6 \mu \mathrm{m}, 0.6$ to $0.7 \mu \mathrm{m}, 0.7$ to $0.8 \mu \mathrm{m}$ and 0.8 to $1.1 \mu \mathrm{m})$. They are called band $4,5,6$ and 7, respectively (NASA 1972, 1976; Tsuchiya 1981a, 1981b).

Signals from the satellite are received and processed at the Earth Observation Center of NASDA (National Space Development Agency of Japan), situated in Saitama Prefectute, northwest of Tokyo.

In 1979 and 1980, two satellites named Landsat-2 and Landsat-3, which have the same characteristics, were operative. Therefore, about 40 images of the same area should have been taken during one year. However, partly due to the troubles of the satellites and partly due to weather conditions, the usable number of images was extremely limited. After careful inspection, there were only nine images which were usable for this research as shown in Table 1.

In this paper, black-and-white images of 4 bands of Landsat MSS, colour composite

Table 1. Landsat MSS data, used in this study.

\begin{tabular}{|c|c|c|c|c|}
\hline No. & Time & $\begin{array}{l}\text { Kind of } \\
\text { Landsat }\end{array}$ & $\begin{array}{l}\text { Cloudiness in } \\
\text { the picture }\end{array}$ & $\begin{array}{l}\text { State of cloud and } \\
\text { around Volcano Aso }\end{array}$ \\
\hline 1 & Mar. $\quad 7,1979$ & 3 & $30 \%$ & $\begin{array}{l}\text { W side of the volcano is } \\
\text { covered with cloud. }\end{array}$ \\
\hline 2 & Sept. 12,1979 & 2 & 30 & $\begin{array}{l}\text { SW side of the volcano is } \\
\text { covered with cloud. }\end{array}$ \\
\hline 3 & Sept. 21, 1979 & 3 & 50 & $\begin{array}{l}\text { Around the volcano is } \\
\text { covered with cloud. }\end{array}$ \\
\hline 4 & Oct. $\quad 9,1979$ & 3 & 30 & No cloud. \\
\hline 5 & Nov. 11,1979 & 3 & 70 & $\begin{array}{l}\mathrm{N} \text { and } \mathrm{W} \text { sides of the volcano } \\
\text { are covered with cloud. }\end{array}$ \\
\hline 6 & Dec. 20,1979 & 3 & 10 & No cloud. \\
\hline 7 & Jan. $\quad 25,1980$ & 3 & 10 & $\begin{array}{l}\text { No cloud, but fallen snow is } \\
\text { detected at the central cone }\end{array}$ \\
\hline 8 & Mar. 19, 1980 & 3 & 0 & No cloud. \\
\hline 9 & Oct. 30,1980 & 2 & 0 & No cloud. \\
\hline
\end{tabular}


images of natural, false and Ektachrome colours are investigated by the optical analysis method.

Through the analysis of the images, the following characteristics are found in those of the respective bands (Tanaka et al. 1980).

Band-4 (0.5-0.6 $\mu \mathrm{m})$ :

Volcanic smoke is recognized clearly. The ridge of the mountain is clear. The urbanized part and the plain area are recognized. Polluted sea water can be detected.

Band-5 (0.6-0.7 $\mu \mathrm{m})$ :

Volcanic smoke and the vegetation-covered area are well recognized.

Band-6 (0.7-0.8 $\mu \mathrm{m})$ :

A fairly large difference, e.g. due to large reflection in the vegetation-covered area, is recognized from those of Bands 4 and 5 . The vegetation-covered area looks white, while the urbanized area has poor reflectance showing dark colours in the image. Light smoke and thin cloud are absent.

Band-7 (0.8-1.1 $\mu \mathrm{m})$ :

The characteristics of this image are similar to those of Band-6. Light smoke and thin cirrus cloud have disappeard. Separation between water and land areas is sharp. Rivers and wet land are well recognized. Bare land rock are visible. Vegetation-covered area has larger reflectance than the urbanized area.

Natural colour:

The natural colour image is made by composition of the three images which get dyed blue in the Band-4 image, red in the Band- 5 image and green in the Band- 6 or -7 image. The topography, volcanic smoke and ash-fall area are recognized clearly in this natural colour image.

False colour :

The false colour image is made by composition of Band-4 image in blue, Band-5 image in green and Band -6 or -7 image in red. The topography, volcanic smoke and ash-fall area are also recognized clearly in this image.

Ektachrome colour:

This colour image is made by composition of three positive black-and-white films of the Landsat image dyed in different colours. In this study, two kinds of Ektachrome colour image were made. One (I) is made by composing three images: Band-4 image in yellow, Band-5 image in cobalt and Band-7 image in magenta, the other (II) by composing Band-4 image in yellow, Band-5 image in magenta and Band-7 image in cobalt. The (I) colour composite image looks dark green in colour, while the (II) looks dark red. These synthetic images, because of different exposures the images of the respective bands, show multifariousness in colour tones, and much information about volcanic smoke and ash covered areas were obtaind.

The above synopsis is shown in Table 2 .

Table 2. Main detectable phenomena and their features on the Landsat MSS images.

\begin{tabular}{|c|c|c|c|c|c|c|c|c|}
\hline \multirow[b]{3}{*}{ Phenomena } & \multicolumn{4}{|c|}{ Black-and-white } & \multicolumn{4}{|c|}{ Colour composite } \\
\hline & \multicolumn{4}{|c|}{ Band } & \multirow{2}{*}{ Natural } & \multirow{2}{*}{ False } & \multicolumn{2}{|c|}{ Ektachrome } \\
\hline & 4 & 5 & 6 & 7 & & & (I) & (II) . \\
\hline Volcanic smoke & A & $\mathrm{B}$ & $\mathrm{C}$ & $\mathrm{C}$ & White & White & Black & White \\
\hline Ash covered area & $\mathrm{C}$ & $\mathrm{C}$ & A & A & Black & Black & White & Blue \\
\hline Bare area & $\mathrm{C}$ & $\mathrm{C}$ & A & A & Black & Black & White & Blue \\
\hline Water and wet area & $\mathrm{C}$ & $\mathrm{C}$ & A & A & Black & Black & Black & Blue \\
\hline Vegetation-covered area & B & $\mathrm{B}$ & $\mathrm{A}$ & A & Green & Red & Green & Red \\
\hline Thin cloud & A & $\mathrm{B}$ & $\mathrm{C}$ & $\mathrm{C}$ & White & White & Black & White \\
\hline
\end{tabular}

A : Good, B: Fair, C: Poor 


\section{Topography and volcanic activity of Volcano Aso}

Volcano Aso has a large caldera surrounded with a somma about $24 \mathrm{~km}$ from noth to south and about $18 \mathrm{~km}$ from east to west. Many cultivated fields and some streets are seen on the caldera floor. Many central cones named Nekodake, Takadake, Nakadake, Kizimadake, Eboshidake, etc., exist in the central part of the caldera. Nakadake is only active cone which has had eruptions in historic times, and has a large crater named Nakadake crater. The size of Nakadake crater is about $1 \mathrm{~km}$ from north to south and about $400 \mathrm{~m}$ from east to west. There are 7 small craters in Nakadake, which are named the 1st crater, the 2 nd crater, $\cdots \cdots$, and 7 th crater, respectively.

The 1st crater is located at the northern most part of Nakadake crater, about $400 \mathrm{~m}$ in diameter. Volcanic smoke is now emitted continuously from this crater, and many eruptions have taken place at this crater in recent years. The strip of ground with a width of $2 \mathrm{~km}$ around Nakadake crater is bare of vegetation owing to a cover of pyroclastic material which was emitted from the crater. Also, a wide bare area is found at the top of Nekodake, another central cone in Volcano Aso. On the other hand, the surface of the other central cones are covered with plants and no bare rock is seen.

The volcanic activity of the 1st crater of Nakadake was very strong from the middle of 1979 through the beginning of 1980 .

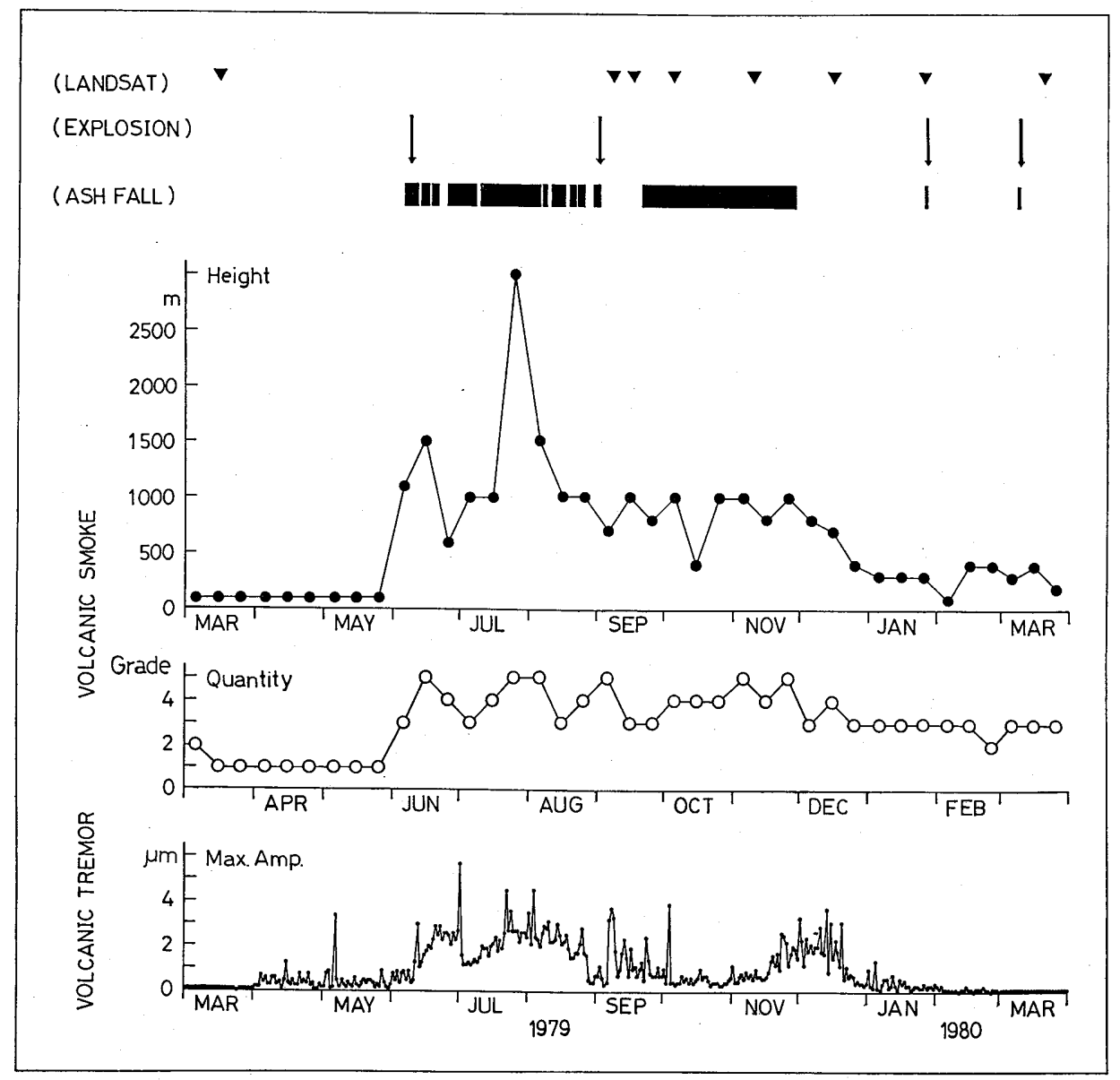

Fig. 1. Volcanic activity at Volcano Aso, and analysis time of the Landsat image. 
A mud emission at the crater bottom took place on June 1, 1979. Many eruptions followed this for the subsequent eight months, the last of them being reported in March 1980.

Fig. 1 indicates the state of volcanic activity of Volcana Aso from 1979 through March 1980, observed at the Aeosan Weather Station. The symbol $\boldsymbol{\nabla}$ of the uppermost row in the Figure indicates the time that the good data of Landsat MSS are available, the arrow in the second row the remarkable eruption, the black band in the third row the period of ash-fall, the solid circle in the fourth row the height of volcanic smoke above the crater rim, the open circle in the fifth row the quantity of volcanic smoke, and the lowest row gives the maximum amplitude of volcanic tremor. The data on volcanic smoke in the figure are the estimated maximum values in every 10 days and those on volcanic tremors are the recorded daily maximums.

The quantity of volcanic smoke is graded by the JMA (Japan Meteorological Agency), in numerals 1 to 7 in increasing order. Explanation of these grades are given in Fig. 2 and Table 3. Relationship between the grade " $Q$ " of quantity and the vertical sectional area " $S\left(\times 10^{4} \mathrm{~m}^{2}\right)$ " of volcanic smoke is expressed by equation (1) (Tanaka 1969).

$$
\log S=0.33 Q+4.33
$$

As seen in Fig. 1, volcanic smoke and tremor became remarkably large during the period from the early June 1979 to the end of January 1980, and ash-fall was observed almost every day between the middle of June and the end of November 1979. The monthly volume of ash-fall is calculated and shown in Fig. 3 and Table 4, and the distribution map of the ash-fall, modified in reference with

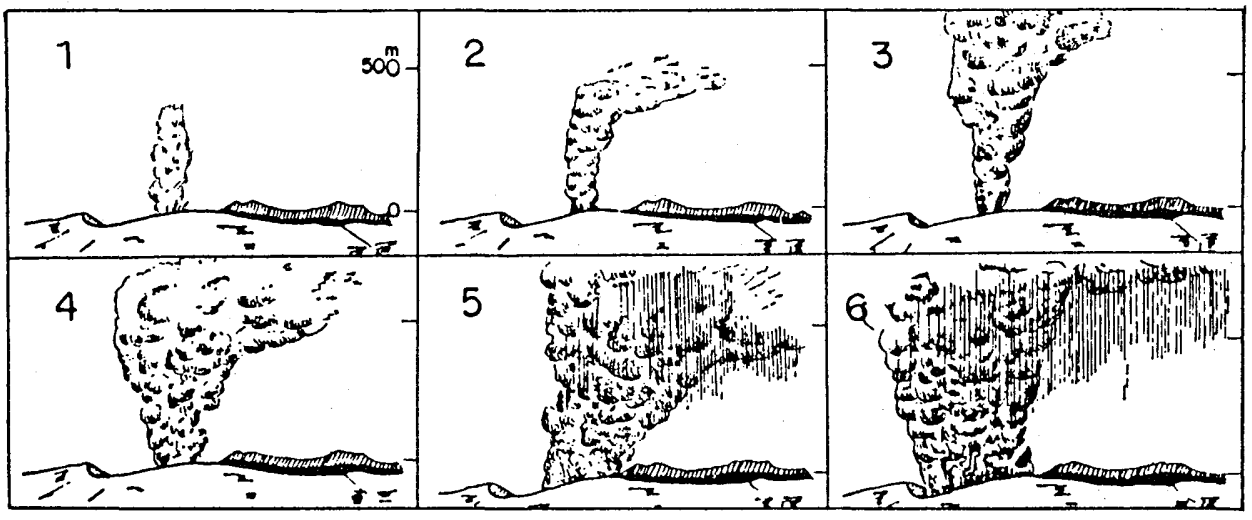

Fig. 2. Illustrations of the grade of volcanic smoke at Volcano Aso.

Table 3. Classification of the quantity of volcanic smoke, provided by JMA.

\begin{tabular}{|c|c|}
\hline Grade & Description \\
\hline 1 & Very little \\
\hline 2 & A little \\
\hline 3 & Medium \\
\hline 4 & Rather heavy \\
\hline 5 & Heavy \\
\hline 6 . & Very heavy \\
\hline 7 & $\begin{array}{l}\text { Extremely heavy. Mountainside is completely covered with } \\
\text { smoke and the smoke often extends above the stratosphere. }\end{array}$ \\
\hline
\end{tabular}


Table 4. Quantity of volcanic ash, emitted from Volcano Aso. (after Asosan Weather Station).

\begin{tabular}{l|r|r|r|r|r|r|r|r|r|r|r}
\hline Year & \multicolumn{9}{c|}{1979} & \multicolumn{2}{c|}{1980} \\
\hline Month & May & Jun. & Jul. & Aug. & Sept. & Oct. & Nov. & Dec. & Jan. & Feb. & Total \\
\hline Quantity & 0 & 142 & 162 & 159 & 30 & 97 & 327 & 0 & 3 & 0 & 920 \\
\hline
\end{tabular}

Unit : $\times 10,000$ ton

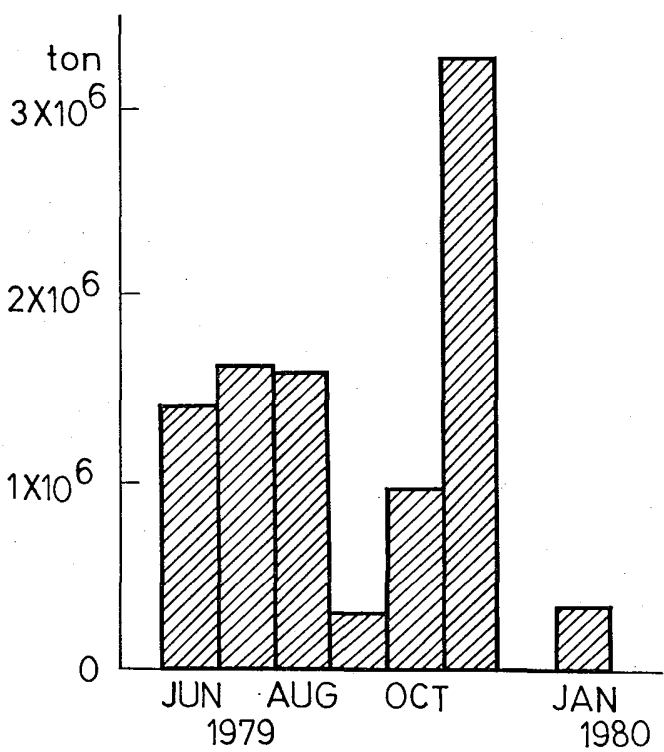

Fig. 3. Monthly quantity of emitted volcanic ash at Volcano Aso.

the observation data by the Asosan Weather Station (1980) is shown in Figs. 4 and 5 respectively.

Almost all the eruption activities of Volcano Aso in the past have produced only a little ash-fall, while the 1979-1980 eruption was peculiar in that it was accompanied by a heavy ash-fall. Especially, in November 1979, a large amount of ash-fall was observed over an extensive area covering the middle of Kumamoto Prefecture, the southwestern part of Ooita Prefecture, the northern part of Miyazaki Prefecture, etc. Therefore, the afflicted area extended scores of kilometers from the active crater, as shown in Fig. 5. It seems that the volcanic smoke in this month spread at least over an area as wide as the abovementiond ash-fall area. The thickness of ash-fall at the crater rim during the active period of 1979 and 1980 had reached

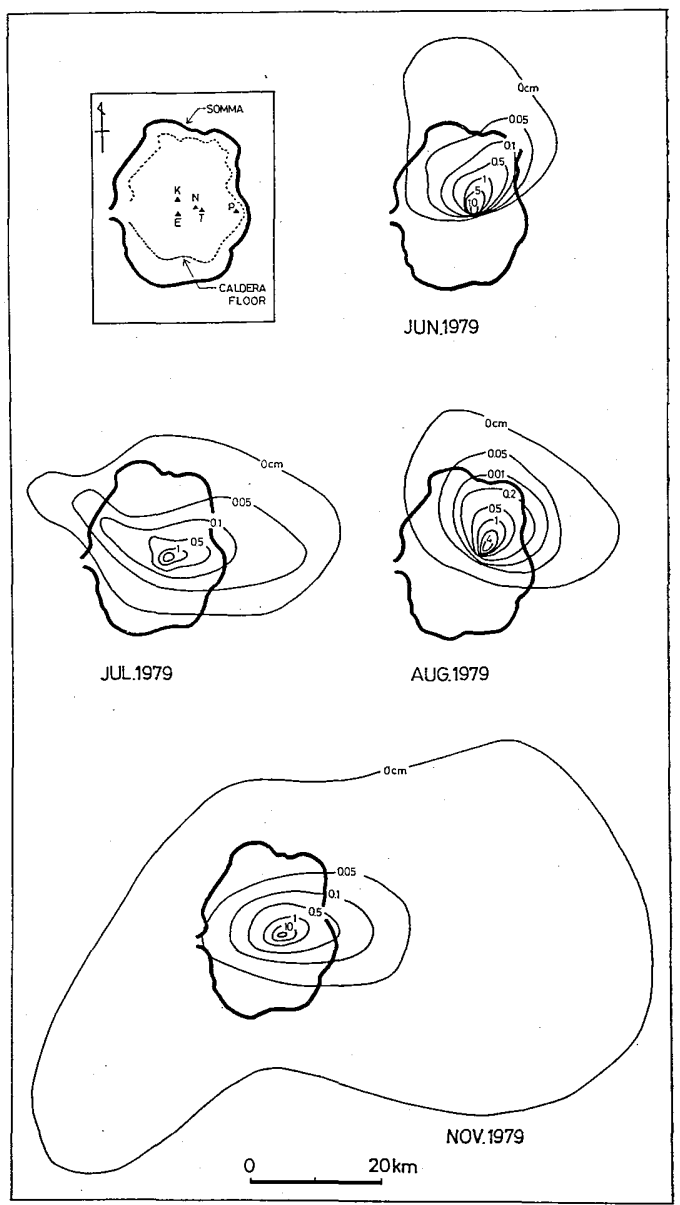

Fig. 4. Monthly distribution of volcanic ash at Volcano Aso.

scores of centimeters, and many plants and facilities for sightseeing near the crater were buried under the heavy ash as shown in Photos 1 and 2.

During the active period of 1979 to 1980 , four large explosive eruptions occurred (June 13, 1979. September 6, 1979. January 26, 1980. March 8, 1980), and volcanic bombs were thrown out around the crater. Especially, 


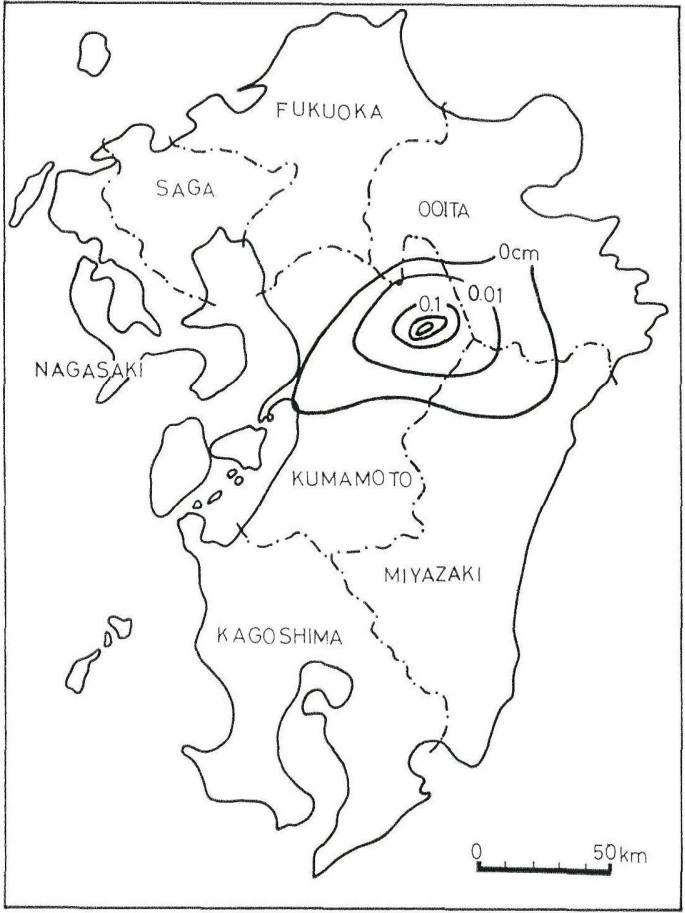

Fig. 5. Distribution of volcanic ash during June to November 1979.

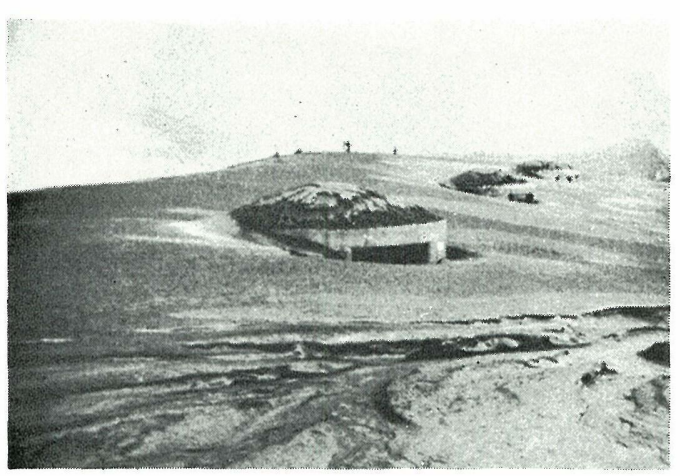

Phot. 1. Evacuation shelter buried deep in volcanic ash at the Nakadake crater rim of Volcano Aso.

the explosive eruption of September 6, 1979 was the largest, and 14 casualites and considerable damage near the crater were reported. The state of volcanic smoke and volcanic ash owing to these four explosive eruptions will be discussed in Section 6 .

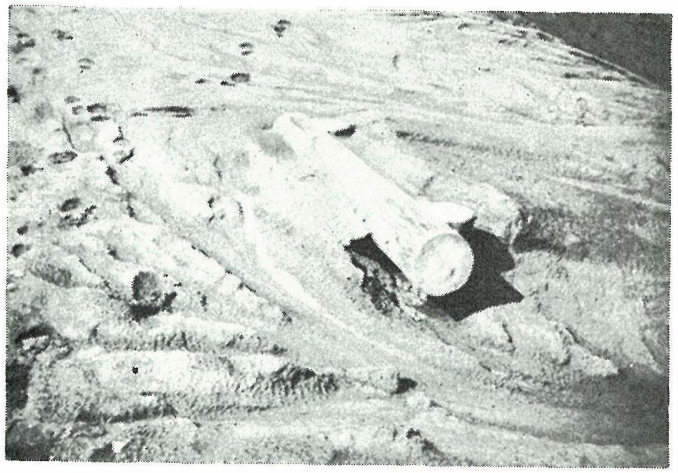

Phot. 2. Wooden fence buried deep in volcanic ash at the Nakadake crater rim of Volcano Aso. Thickness of ash is about $60 \mathrm{~cm}$.

\section{Form of Volcano Aso, detected from the Landsat MSS image}

Owing to the quality of the Landsat MSS image and the large scale of the topography of Volcano Aso as mentioned in the foregoing sections, it is possible to detect the topography of Volcano Aso from the Landsat MSS image. The outline of the topography of Volcano Aso was read from the natural colour image and false colour image of the Landsat MSS.

Photos 3 and 4 are the Landsat MSS images that were taken on October 9, 1979. Photo 3 is a natural colour image of a wide northern Kyushu area (PATH-121, ROW-37 in the World Reference System to identify Landsat images), while Photo 4 is a false colour image of a restricted Aso area. These images are shown in such a way that the vertical line in this photo points upward the north-northeast. The outlines of the topography and state of volcanic smoke, etc., in Photo 4 are shown in Fig. 6 on the same scale as in Photo 4.

The form of the caldera in the Landsat MSS image is highlighted by the dark-coloured somma and by the contrastive boundary line between caldera floor and caldera wall, which are due to sunlight falling on different topographies. Therefore, a good agreement is seen between the Landsat MSS image and topographical map of Volcano Aso. 


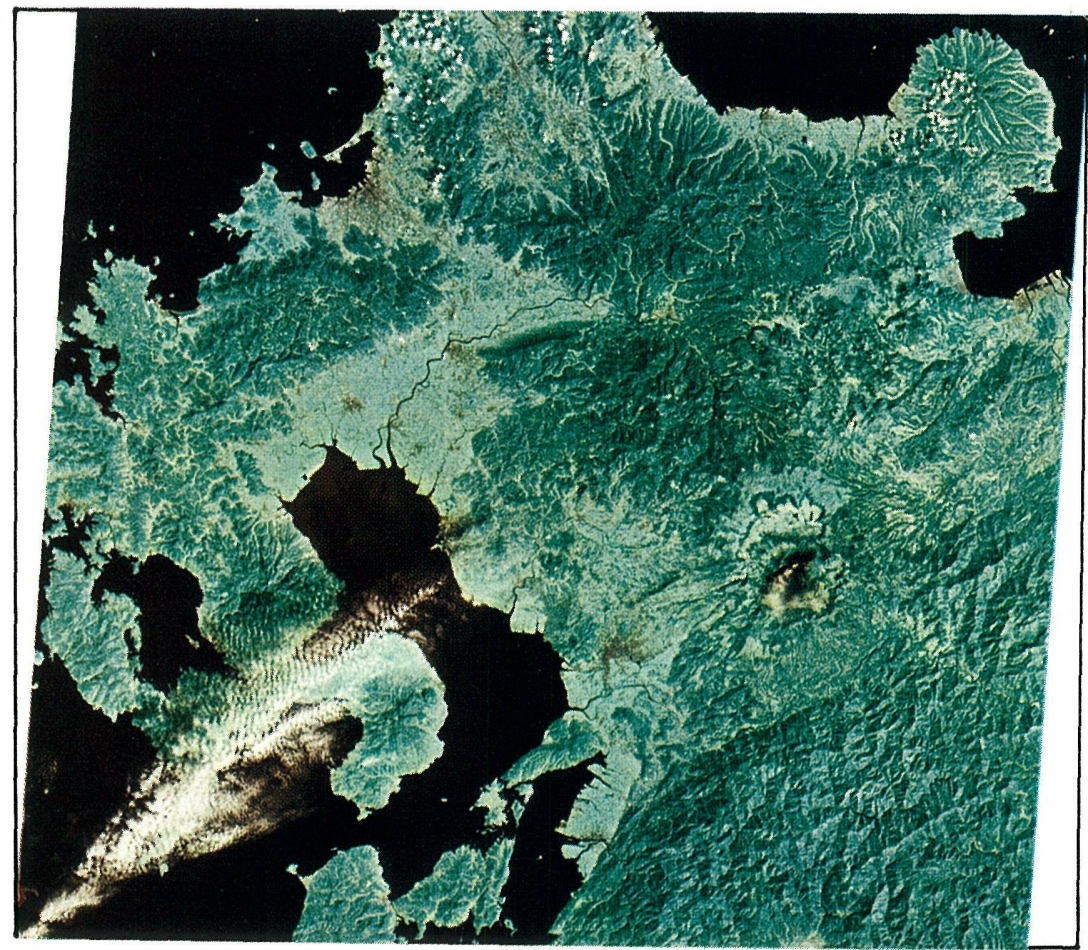

Phot. 3. Image of the northern Kyushu Area (PATH-121, ROW-37) including Volcano Aso, taken from the Landsat, on October 9, 1979. This photo is in natural colour.

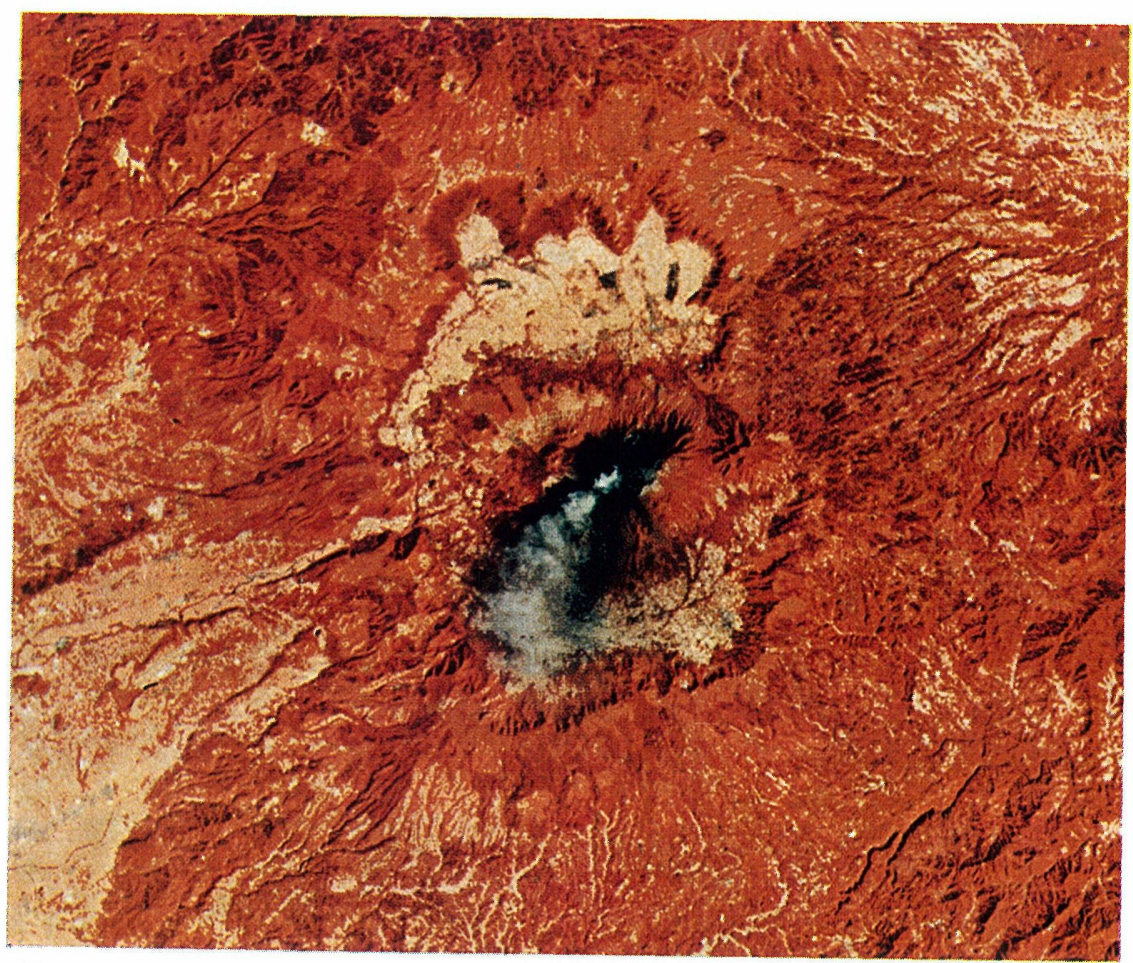

Phot. 4. Image of Volcano Aso, photographed from the Landsat, on October 9, 1979. This photo is in false colour. 


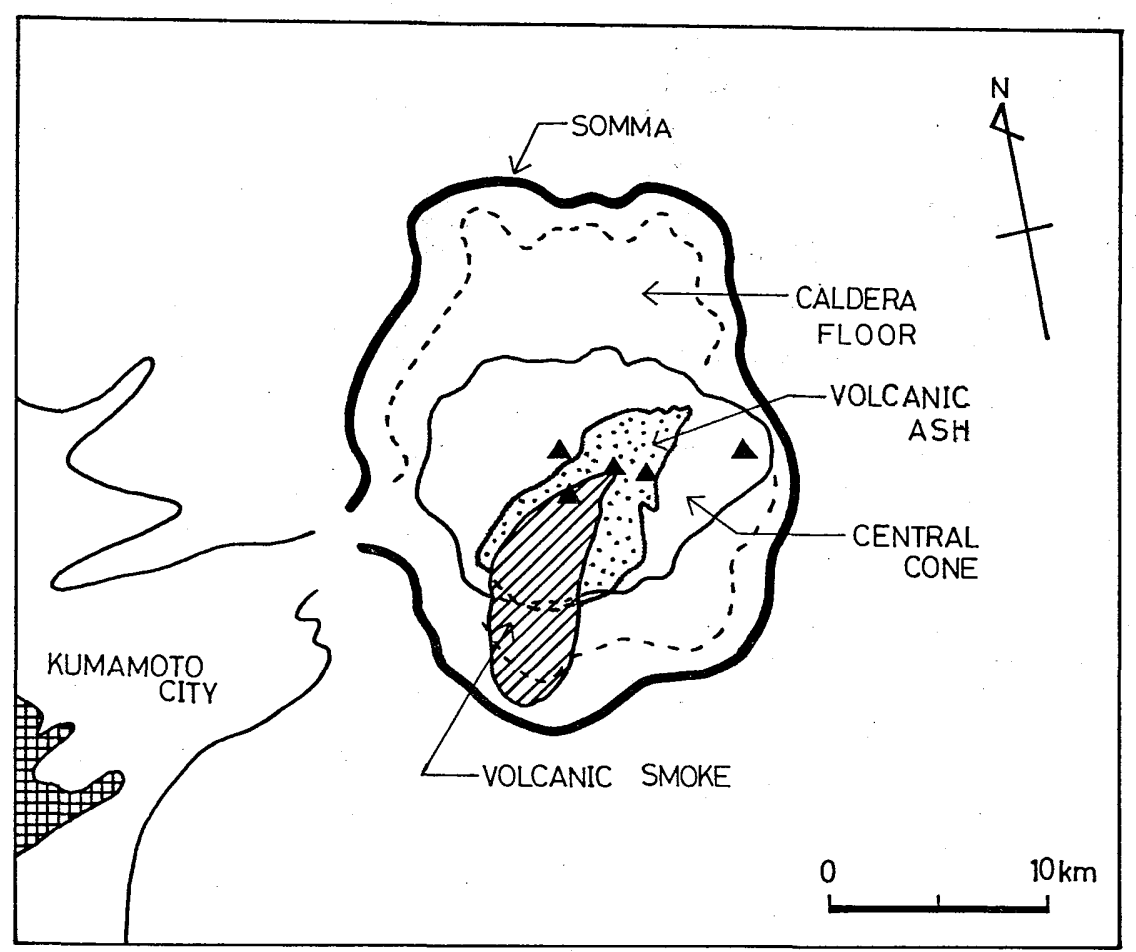

Fig. 6. The map in and around Volcano Aso.

In natural colour images, white or light blue in colour in the northern half and the southern part of the caldera floor is mainly an agricultural area. In this area, there are many paddy fields, cultivated fields and streets. The streets of the city are seen to be small spots in violet colour by the natural colour image, but in light blue colour by the false colour image.

Volcanic smoke and bare land including ash-fall areas are well recognized by colour images. The former is white in colour, the latter black or brown. The brightness of colour of the bare land and ash-fall area is nearly the same, and hard to classify.

Moreover, the black-and-white images of the 4 bands of the Landsat MSS and Ektachrome colour images (i.e. the brightness and colour of the phenomena associated with the volcanic activity shown in Table 2) are also made use of in recognizing the features of Volcano Aso.

Many shadows of clouds on the ground are visible, but no shadows are seen in most cases of volcanic smoke, since volcanic smoke is thin.

Thus the state of Volcano Aso can be detected in detail from the Landsat MSS images.

\section{Detection of volcanic smoke and ash-fall area from the Landsat MSS data}

The nine images listed in Table 1 are looked through an optical magnifier, and the area of spreading volcanic smoke and the area covered with volcanic ash were detected by the optical analysis method with reference to the topography of Volcano Aso and the features of brightness of the ground in the image as shown in Section 3 and 4. Seasonal variations in reflectance on the ground due to change of vegetation were seen in the images. However, no change was seen in the image of volcanic smoke and volcanic ash, and it was easy to detect them.

The results of analysis are shown in Fig. 7. In this figure are shown the form 


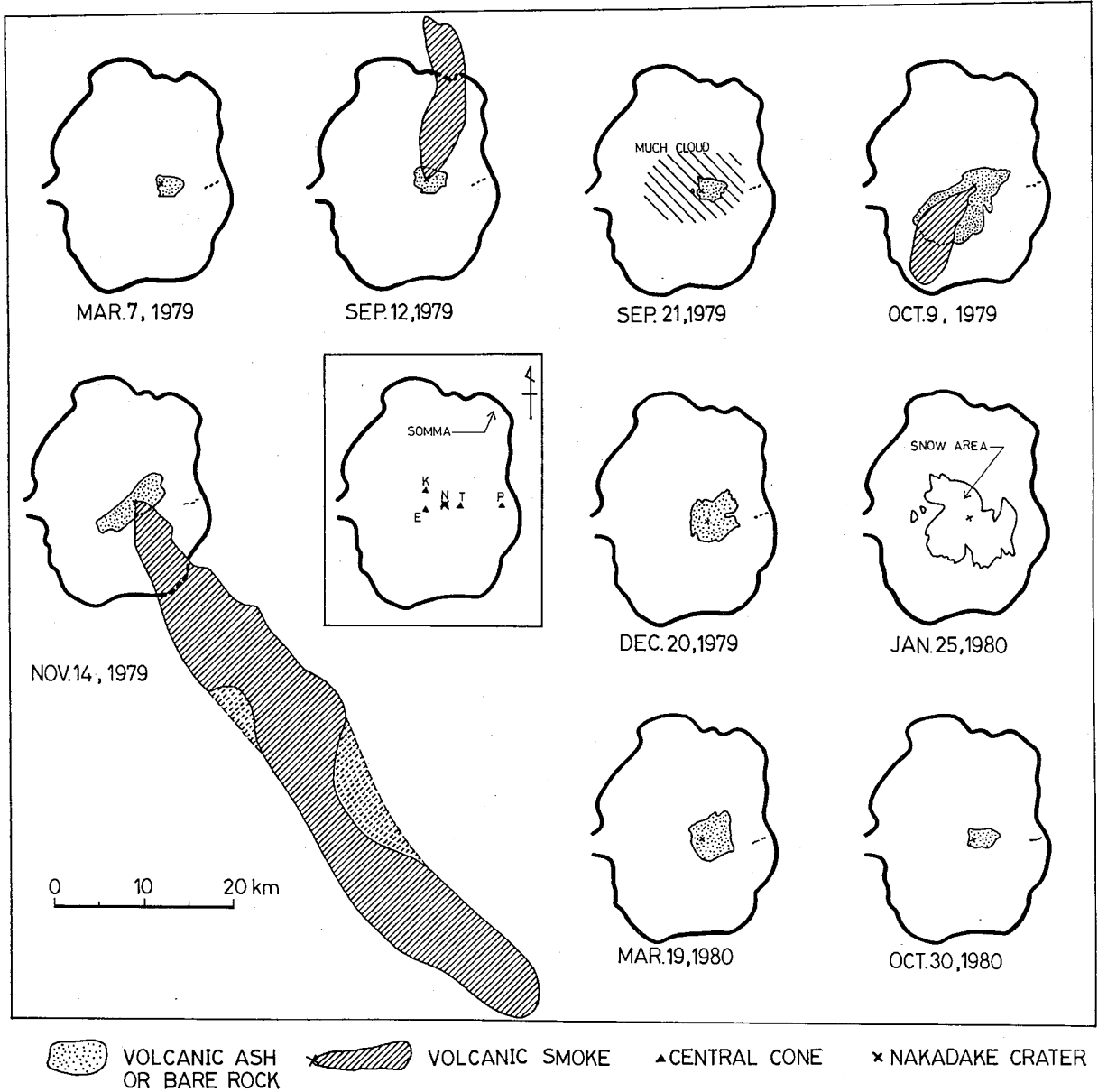

Fig. 7. Figures of the area covered with volcanic smoke and ash including bared are at Volcano Aso, as decided from the Landsat MSS data. A : Central cone, E: Eboshidake, K: Kizimadake, N : Nakadake, T: Takadake, P: Nekodake. Small spots of eastern caldera are bared rock area of Nekodake.

of the Aso caldera, location of the central cones, area of volcanic smoke spreading and area covered with volcanic ash including the bare area. The state of volcanic smoke and volcanic ash by eye observation at the Asosan Weather Station, at the same time as the Landsat data, is shown in Table 5.

The remarkable volcanic eruptions of Volcano Aso took place during the period from June through November in 1979 as mentiond in Section 3, and the extensive volcanic smoke rising from the crater and the area covered with volcanic ash around the crater are detected in the Landsat image including this period. The results obtained are as follows:

1). The image of March 7, 1979 (before the eruption period)

Very little smoke was detected above the crater, nor any volcanic ash. A wide bare area around the top of the central cones of Takadake and Nakadake was detected. Long slender bare rock lines running in the eastwest direction at the Nekodake were detected.

2). The image of September 12, 1979

A large volcanic smoke from the crater over the north somma, and a ash-fall area near the crater were detected.

3). The image of September 21, 1979

Owing to a large cloud coverage the 
Table 5. Volcanic smoke and area covered with volcanic ash at Volcano Aso.

\begin{tabular}{|c|c|c|c|}
\hline Date & $\begin{array}{l}\text { Smoke } \\
\text { and ash }\end{array}$ & Detected feature & $\begin{array}{l}\text { Observation from the } \\
\text { Asosan Weather Station }\end{array}$ \\
\hline Mar. 17, 1979 & $\begin{array}{l}\text { Smoke } \\
\text { Ash } \\
\text { Others }\end{array}$ & $\begin{array}{l}\text { Spread } 100 \mathrm{~m} \times 200 \mathrm{~m} \text { above the crater. } \\
\text { None. } \\
\text { A bared rock area of } 3 \mathrm{~km} \times 2 \mathrm{~km} \text { is } \\
\text { detected at Nakadake and Takadake. } \\
\text { Bared rock lines about } 2 \mathrm{~km} \text { long } \\
\text { are detected at Nekodake. }\end{array}$ & $\begin{array}{l}\text { None. Activity: calm. } \\
\text { None. }\end{array}$ \\
\hline Sept. 12, 1979 & $\begin{array}{l}\text { Smoke } \\
\text { Ash }\end{array}$ & $\begin{array}{l}\text { Spread from the crater to } 20 \mathrm{~km} \mathrm{~N} \text {. } \\
\text { Covered } 4 \mathrm{~km} \times 3 \mathrm{~km} \text { around the crater. }\end{array}$ & $\begin{array}{l}\text { Colour: white. } \\
\text { Quantity: grade } 2 . \\
\text { Height: } 1000 \mathrm{~m} . \\
\text { Activity : eruption stage. } \\
\text { Observed. }\end{array}$ \\
\hline Sept. 21, 1979 & Smoke & $\begin{array}{l}\text { Unknown owing to cloud. } \\
\text { Covered } 4 \mathrm{~km} \times 3 \mathrm{~km} \text { around the crater. }\end{array}$ & $\begin{array}{l}\text { Colour: white. } \\
\text { Quantity : grade } 2 . \\
\text { Height : } 200 \mathrm{~m} . \\
\text { Drifting direction from } \\
\text { the crater: NW. } \\
\text { Observed. }\end{array}$ \\
\hline Oct. 9,1979 & Ash & $\begin{array}{l}\text { Spread from the crater to } 12 \mathrm{~km} \mathrm{SW} \text {. } \\
\text { Covered } 10 \mathrm{~km} \times 5 \mathrm{~km} \text { around the crater. }\end{array}$ & $\begin{array}{l}\text { Colour: gray. } \\
\text { Quantity: grade } 3 . \\
\text { Height : } 400 \mathrm{~m} . \\
\text { Drifting direction from } \\
\quad \text { the crater: } \mathrm{S} \text {. } \\
\text { Activity : eruption stage. } \\
\text { Observed. }\end{array}$ \\
\hline Nov. 14, 1979 & Smoke & $\begin{array}{l}\text { Spread from the crater to } 70 \mathrm{~km} \mathrm{SE} \text {. } \\
\text { Covered } 10 \mathrm{~km} \times 3 \mathrm{~km} \text { around the crater. }\end{array}$ & $\begin{array}{l}\text { Colour: gray. } \\
\text { Quantity : grade } 4 . \\
\text { Height: } 400 \mathrm{~m} . \\
\text { Drif ting direction from } \\
\text { the crater: } \mathrm{S} \text {. } \\
\text { Activity : eruption stage. } \\
\text { Observed. }\end{array}$ \\
\hline Dec. 20,1979 & Smoke & $\begin{array}{l}\text { Spread } 100 \mathrm{~m} \times 300 \mathrm{~m} \text { above the crater. } \\
\text { A fallen ash area or a bared area of } \\
5 \mathrm{~km} \times 5 \mathrm{~km} \text { is detected around the } \\
\text { crater. }\end{array}$ & $\begin{array}{l}\text { Colour: white. } \\
\text { Quantity : grade } 1 . \\
\text { Height: } 200 \mathrm{~m} . \\
\text { Drifting direction from } \\
\text { the crater: unknown. } \\
\text { Activity : calm. } \\
\text { None. }\end{array}$ \\
\hline
\end{tabular}


Table 5. (continued)

\begin{tabular}{|c|c|c|c|}
\hline Date & $\begin{array}{l}\text { Smoke } \\
\text { and ash }\end{array}$ & Detected feature & $\begin{array}{l}\text { Observation from the } \\
\text { Asosan Weather Station }\end{array}$ \\
\hline Jan. 25, 1980 & $\begin{array}{l}\text { Smoke } \\
\text { Ash }\end{array}$ & $\begin{array}{l}\text { Unknown owing to fallen snow. } \\
\text { Unknown. }\end{array}$ & $\begin{array}{l}\text { Colour: white. } \\
\text { Quantity: grade } 2 . \\
\text { Height: } 100 \mathrm{~m} . \\
\text { Drifting direction from } \\
\text { the crater: } \mathrm{S} \text {. } \\
\text { Activity : calm. } \\
\text { None. }\end{array}$ \\
\hline Mar. 19, 1980 & Ash & $\begin{array}{l}\text { Spread } 100 \mathrm{~m} \times 200 \mathrm{~m} \text { above the crater. } \\
\text { A fallen ash area or bared area of } \\
5 \mathrm{~km} \times 4 \mathrm{~km} \text { is detected around } \\
\text { the crater. }\end{array}$ & $\begin{array}{l}\text { Colour : white. } \\
\text { Quantity : grade } 2 . \\
\text { Height: } 100 \mathrm{~m} . \\
\text { Drifting direction from } \\
\text { the crater: } \mathrm{S} \text {. } \\
\text { Activity : calm. } \\
\text { None. }\end{array}$ \\
\hline Oct. 30,1980 & Smoke & $\begin{array}{l}\text { Very little above the crater. } \\
\text { None. } \\
\text { A bared area of } 3 \mathrm{~km} \times 2 \mathrm{~km} \text { is detected. } \\
\text { Its size and location are nearly the } \\
\text { same as on Mar. } 17,1979 \text {. }\end{array}$ & $\begin{array}{l}\text { Colour: white. } \\
\text { Quantity: grade } 1 . \\
\text { Height: } 200 \mathrm{~m} . \\
\text { Drifting direction from } \\
\text { the crater: } \mathrm{E} . \\
\text { Activity : calm. } \\
\text { None. }\end{array}$ \\
\hline
\end{tabular}

details of volcanic smoke were not detected, but part of the ash-fall area was detected in the space between clouds as shown in Fig. 7 .

4). The image of October 9, 1979 (this image is shown in Photos 3 and 4, and Fig. 6)

Volcanic smoke extending from the crater to the southwest somma, and a large area of volcanic ash-fall were detected.

5). The image of November 14, 1979

Volcanic smoke spreading out about 70 $\mathrm{km}$ southeast from the crater was detected. A wide ash-fall area covering about half of the central cones was detected. The colour of the smoke in the distance was light; but it was dark inside the somma.

6). The image of December 20, 1979 (no eruption was reported near this day)

Very little volcanic smoke was detected above the crater. A wide bare area at Naka- dake and Takadake was detected. The size of this bare area was larger than that on March 7, 1979. The reason is that the volcanic ash covered area was added around the original bare area.

7). The image of January 25, 1980

Owing to the snow cover over the area including the central cone, no volcanic smoke and ash-fall and bare area could be detected.

8). The image of March 19, 1980

Very little volcanic smoke was detected above the crater. A wide bare area of the same size observed in the image of December 20, 1979 was detected. The size of this bare area was larger than that of March 7, 1979, the same season of the preceding year. It seems that the plants of Nakadake and Takadake were buried deep in volcanic ash, so the wide area was turned to bare land, and this state continued until the calm stage. 
9). The image of October 30,1980 (taken after a long lapse of time from the eruption)

The size of the bare area detected in this image is nearly the same as that of March 17, 1979, taken before the eruption. It seems that the influence of ash-fall which buried the plants had faded away by the end of October 1980.

As mentiond above, the area of volcanic smoke spreading and the area covered with volcanic ash were clearly detected from the Landsat image. However, the area of ash-fall detected was smaller than that of the area indicated in the map of monthly ash-fall distribution shown in Figs. 4 and 5. Therefore, the area of ash-fall detectable from the image seems to show only the area covered with heavy ash-fall. In the case of the study of ash-fall at the 1979 eruption of Volcano Ontake, central Japan, the area of ash-fall with a thickness of more than $1 \mathrm{~mm}$ was detected in the Landsat MSS data (Tsuchiya et al. 1980). Therefore, the area of ash-fall of Volcano Aso detectable from the Landsat MSS data also seems to be smaller than the area obtained by eye observation from the ground.

\section{Volcanic smoke at the explosive eruption}

At the calm stage of Volcano Aso, a light white smoke of grade " 1 " in quantity rises to about $100 \mathrm{~m}$ in height. This type of smoke does not spread wide, while during the period of eruptive activity, volcanic smoke changes black in colour and grows to grade "2" to " 4 " in quantity, and flows over distances. Especially, a large scale of smoke of grade " 5 " or more is seen at a few large explosive eruptions.

The grade of quantity of volcanic smoke is influenced by the pressure and the volume of the smoke emitted, wind speed of high altitudes and other atmospheric conditions. In the case of Volcano Aso, the relationship between height " $h$ (meter)" and the grade of volcanic smoke is expressed by equation (2)
(Tanaka 1969), where $Q$ is the grade ranging from 1 to 7 , provided by JMA.

$$
\log h=0.17 Q+2.31
$$

Four large explosive eruptions were reported at Volcano Aso during the period from June 1979 to March 1980. Unfortunately, no image of the Landsat was taken at the time of these large eruptions, so the state of volcanic smoke was studied with reference to the above equation and by the observed data of the Asosan Weather Station. The results obtained are as follows:

1). The 1 st explosive eruption $(15 \mathrm{~h} 10 \mathrm{~m}$, June 13, 1979)

Black smoke rose to $1500 \mathrm{~m}$ in height. The grade of quantity of smoke was 5 . Volcanic cinders were emitted up to $400 \mathrm{~m}$ above the crater rim. A $10 \mathrm{~cm}$ thickness of ash-fall was observed about $1 \mathrm{~km}$ north from the crater. The size of this volcanic smoke was the largest one during this month, so it seems that the smoke spread at least to the same length as the ash-fall shown in Fig. 4. Ash and smoke flowed out as far as about $30 \mathrm{~km}$ north from the crater.

2). The 2 nd explosive eruption $(13 \mathrm{~h} 06 \mathrm{~m}$, September 9, 1979)

Black smoke rose to $700 \mathrm{~m}$ in height, and flowed $45 \mathrm{~km}$ in the northeast direction. The grade of quantity of smoke was 5 . A hill of $30 \mathrm{~m}$ in height located on the 1st crater bottom was blown away by this explosion (Tanaka et al. 1980). Volcanic cinders reached $1.2 \mathrm{~km}$ northeast from the crater. Casualties and damage were caused as mentiond in Section 2 .

3). The 3rd explosive eruption ( $21 \mathrm{~h} 07 \mathrm{~m}$, January 26, 1980)

The colour of smoke was unknown owing to dark night. Volcanic smoke rose to $500 \mathrm{~m}$ in height. The grade of quantity of smoke was estimated at 2.3 with reference to the height of smoke and equation (2). Ashfall was extensively observed as far as 10 $\mathrm{km}$ north from the crater. The thickness of ash-fall at the crater rim was 2 to $3 \mathrm{~cm}$.

4). The 4 th explosive eruption $(08 \mathrm{~h} 07 \mathrm{~m}$, March 8, 1980) 
Grayish white smoke rose as high as $300 \mathrm{~m}$. The grade of quantity of smoke was estimated to be 3 . In this case, the amount of ash-fall was small in quantity and the area afflicted was limited within $200-300 \mathrm{~m}$ southwest from the crater.

The relationships between height $(\mathrm{h}: \mathrm{m})$ and length $(\mathrm{D}: \mathrm{km})$ of spreading smoke and that of quantity $(\mathrm{Q}: 1-7)$ and length $(\mathrm{D}: \mathrm{km})$

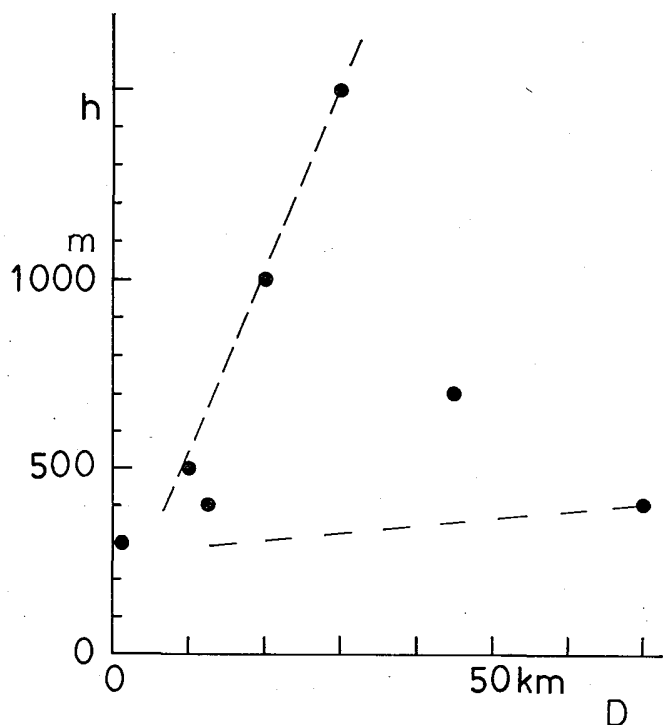

Fig. 8. Relationship between height $(\mathrm{h}: \mathrm{m})$ and maximum length (D: km) of spread volcanic smoke.

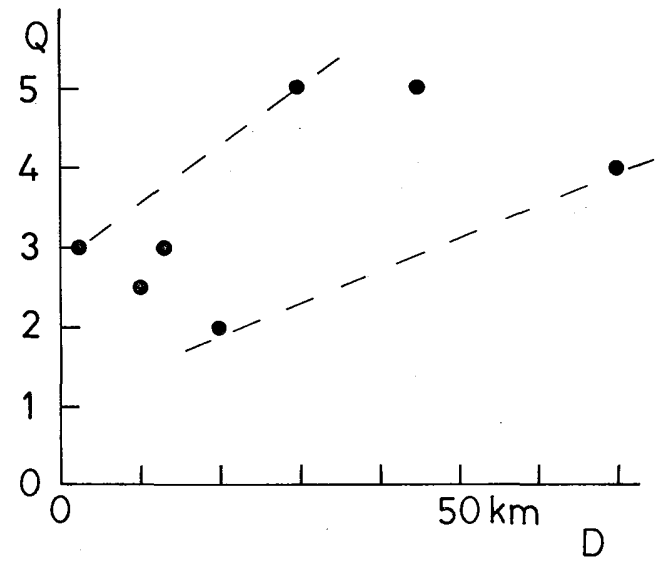

Fig. 9. Relationship between quantity (Q: 1-7) and maximum length $(D: \mathrm{km})$ of spread volcanic smoke. are shown in Figs. 8 and 9 respectively. The data on volcanic smoke in the Figures are those of the above mentioned four eruptions and the volcanic smoke described from the Landsat image shown in Section 5. The spread of volcanic smoke is limited to the region between the two broken lines in the Figures. Thus, if the height or quantity of volcanic smoke is known by eye observation from the ground, its length will be obtained from these Figures.

\section{Conclusion and discussion}

The extent of volcanic smoke and ashfall of Volcano Aso was detected from the Landsat MSS image, and the following results were obtained :

1). The volcanic smoke was clearly recognized in the Band-4 $(0.5-0.6 \mu \mathrm{m})$ image while the ash-fall area was recognized in the Band-6 (0.7-0.8 $\mu \mathrm{m})$ and $-7(0.8-1.1 \mu \mathrm{m})$ images. The colour composite image made through the combination of Band-4, -5 and -7 data were also effective for identifying both smoke and ash-fall area.

2). Volcano Aso showed very strong eruption activities during the period from 1979 through 1980, and the wide area of volcanic smoke and ash was often detected in the Landsat MSS image. The detectable area of the maximum extension of volcanic smoke at this period through MSS image analysis was about $70 \mathrm{~km}$ from the crater, and that of volcanic ash was approximately $10 \mathrm{~km}$ around the crater.

3). Many plants were buried in volcanic ash, and the influence of ash-fall continued for a long time. In regions 2 to $3 \mathrm{~km}$ from the crater, no regermination was seen for 10 months after the last ertption.

4). The area of ash-fall detectable from the Landsat MSS image seems to show only an area covered with heavy ash-fall.

5). A certain relationship between the height and quantity of volcanic smoke was obtained, but no definite relationship was obtained between both phenomena and the spatial extent of volcanic smoke, which sug- 
gests that atmospheric conditions exert a fairly strong influence on the phenomena. It is necessary to study the relationship between volcanic smoke and weather conditions.

6). The eye observation of volcanic smoke and ash-fall of this volcano has routinely been carried out by the Asosan Weather Station. By this observation, it is possible to get information on the vertical extent or height of volcanic smoke and the grade of ash-fall, but difficult to get information on the horizontal distribution of volcanic smoke or ash-fall. The Landsat MSS image can supply valuable information on the areal extent of volcanic smoke and ash-fall. Therefore, it can make up for the weak points of eye observation from the ground.

The Landsat MSS image gives so much information about volcanic activities that the data from the Landsat are very useful for volcano observation.

In view of the efficiency and usefulness of the satellite in the observation of volcanic activities, it is desirable that scientists in volcanology actively participate in designing on-board sensors of the spacecraft.

Since the chances of having a cloudless sky are very scarce, a few more satellites with better spatial and spectral resolution are required.

Finally the authors wish to thank Dr. Mamoru Katsumata and Dr. Masaaki Seino for the suggestions and helpful advice given throughout this study, and also Miss Michiko
Someno for her assistance in drafting the figures.

\section{References}

Asosan Weather Station, 1980: Volcanic activity of Aso in 1979. Report. Coordinating Committee for Prediction of Volcanic Eruption, 20, 17-20. (in Japanese)

Friedman, J.D., G. Heiken, D. Randerson and D.S. Mckay, 1976: Observation of eruption clouds from Sakura-zima volcano, Kyushu, Japan from Skylab 4. Jour. Volcanol. Geotherm. Res., 1, 305-329.

NASA, 1972: Earth Resources Technology Satellite data users handbook. NASA Document No. 71 SD4249.

- 1976: Landsat users handbook.

Tanaka, Y., 1969: Statistical analysis of volcanic smoke (Part 1). Quart. Jour. Seismol., 32, 37-50. (in Japanese).

Tanaka, Y., K. Tsuchiya and T. Yamaura, 1980: Detection of volcanic ash coverage of the 1979 eruption activity of Mt. Aso, from Landsat MSS data. Bull. Volcanol. Society of Japan. 25, 116. (in Japanese).

Tanaka, Y., Y. Sawada and M. Churei, 1980: Heat discharge estimation at the active crater of Aso Volcano. Bull. Volcanol. Society of Japan. 25, 229. (in Japanese).

Tsuchiya, K., S. Uehara, Y. Tanaka, H. Ohnuki and H. Ochiai, 1980: Detection of volcanic ash coverage from Landsat MSS data. Adv. Space Res. COSPAR., 1, 121-128.

Tsuchiya, K., 1981a: Overview on earth observation satellite Landsat and remote sensing. Applied Physics, 50, 655-660.

- - 1981b: Japanese Landsat ground station. Japan International Cooperation Agency. 1-40.

\title{
ランドサットによる阿蘇山の噴煙と降灰の調査
}

\author{
田中康裕・土屋 清* ・ 山浦雄一*
}

\footnotetext{
大噴火の際の噴㖶や降灰域は広い範困に及ぶので，その全容を地上から観測することはきわめてむずかしく，人 工衛星からの観測が有効である。

1979〜80年には阿蘇山で活発な噴火活動があり，同火山としてはまれに見る多量の噴煙と火山灰を放出した。そ こで, この時期に地球観測衛星ランドサットが撮影した映像から，噴煙の広がり具合括よび降灰域を検出し，阿蘇 山測候所が地上から行った火山観測結果と比較した。これは人工衛星の火山観測への利用を検討するのによい機会 であった。

ランドサットの MSS は波長別に 4 つのバンドに分れて扣り，それぞれバンド 4 ，バンド 5 ，バンド 6 ，バンド 7 と呼ばれている。バンド別の白黒映像と, それらを合成して得られるェクタクロームカラー写真, ナチュラルカ
} 
ラー写真, フォールスカラー写真等から, 映像内容を光学的手法により判読した。

噴煙はバンド 4 によく写って拉り，降灰域や裸地はバンド 6 执よび 7 によく現わ机ていたので，それらのバンド の映像を強調することにより噴煙の広がり具合や降灰域が容易に求められた。

火山活動が静かな時期の阿蘇山中岳火口の噴煙は，ランドサットの映像にはわづかしか写っていなかったが，噴 火活動期の映像には最大長 $70 \mathrm{~km}$ にも及ぶ広大な噴煙と, $10 \mathrm{~km}$ にも及ぶ降灰域が認められた。また，火口から $2 \sim 3 \mathrm{~km}$ 離れた所でも，降灰のため裸地化して植物の生觉ない期間が，噴火後 10 ケ程度も続いていたことが映 像の解析からわかった。

地上観測では噴煙の垂直的広がり（高さ）や降灰の強さはわかるが，それらの水平的広がり具合はわからない。 ランドサット映像では, 噴㻺, 降灰域の水平的広がりがわかるので, 地上観測の弱点を補うことができる。地上観 測で求めた噴煙の量や高さとランドサットの映像から求めた噴㖶の流跡の長さとの関係は複雑であることがわかっ た。

ランドサットの映像は地上では観測不可能な広域にわたる現象も一目で把握できるので，広域火山監視へ利用で きる。さらに，火山観測にも利用できる装置を持った多数の衛星が運行されるならば，常時火山監視に役立つであ ろう。

* 宇宙開発事業団 